\title{
Characteristics of Spontaneous Combustion of Anthracite in Vietnamese Coal Mines*
}

\author{
by Le Trung TUYEN ${ }^{\mathrm{a}}$, Nhu Viet TUAN ${ }^{\mathrm{b}}$, \\ Kotaro OHGA ${ }^{\mathrm{c}}$ and Takehiro ISEI ${ }^{\mathrm{d}}$
}

\begin{abstract}
Including Vietnamese anthracite coal mines, it had been said that anthracite coal mine hardly starts spontaneous combustion ${ }^{1)}$; however, at some of underground anthracite coal mines of Vietnam, several outbreaks of spontaneous combustion have been reported since 2004. The authors have been involved into site investigation, countermeasures as well as analysis of the data of those anthracite coal mines and one sub-bituminous coal mine in northern part of Vietnam. In this paper, special characteristics of spontaneous combustion of anthracite coal mines and a sub-bituminous coal mine and site counter measures are discussed. Indication gasses of spontaneous combustion of anthracite might be limited into only $\mathrm{CO}$ and $\mathrm{H}_{2}$ gasses in contrast with the cases of spontaneous combustion of bituminous, which generate many kinds of hydrocarbon gasses. From the view point of prevention of spontaneous combustion, problems of site mining conditions are also discussed.
\end{abstract}

KEY WORDS: Spontaneous Combustion, Anthracite, Coal Mine, Vietnam, Indication Gasses

\section{Introduction of Vietnamese coal mines}

Major Vietnamese coal fields locate in several provinces of northern part of Vietnam in which Quang Ninh province produces the mass part of coal in Vietnam from both open pit and underground mines. Most of those coal mines produce anthracite. In Vietnam the demand for coal is rapidly increasing in recent years at a rate around $15 \%$ per year, which is more than double of economic growth rate and resulted into increase of underground production ratio up to nearly $55 \%$. Annual coal production in 2015 was 37.75 million tons of which 20.1 million tons were produced from underground coal mines.

Recently, Vietnam National Coal and Mineral Industry Group (VINACOMIN) has announced twelve coal mine fires at four underground coal mines which have been considered as coal spontaneous combustion at Hong Thai, No. 91 Enterprise, Khanh Hoa and Phan Me coal mines. Former three coal mines all produce anthracite and locate in the west part of Quang Ninh Coal Basin. Phan Me Coal Mine produces sub-bituminous and locates in Thai Nguyen Coal Basin. At the east part of Quang Ninh Coal Basin, no any outbreak of spontaneous combustion has been reported up to date. The locations of these Coal Basins are shown in Fig. 1 $^{2)}$.

\section{History of spontaneous combustions in Vietnamese coal mines}

A history of coal spontaneous combustions in Vietnamese anthracite coal mines are summarized in Table 1. The first outbreak of spontaneous combustion in Vietnamese anthracite

*Received 7 July, 2016; accepted for publication 13 October, 2016

a. Master of Engineering, Deputy Director of Mine Safety Center, IMSAT,

VINACOMIN of Vietnam, No. 9 Area, Quang Trung Ward, Uong Bi City, Quang

Ninh Province, Vietnam

b. Former Director, Mine Safety Center, IMSAT, VINACOMIN of Vietnam

c. NPO Underground Resources Innovation Network, 9-15 Nishioka 5jo 14choume,

Toyohira-ku, Sapporo Japan

d. Dr., Advisor to IMSAT, VINACOMIN of Vietnam

[For Correspondence] E-mail: trungtuyenatm@gmail.com
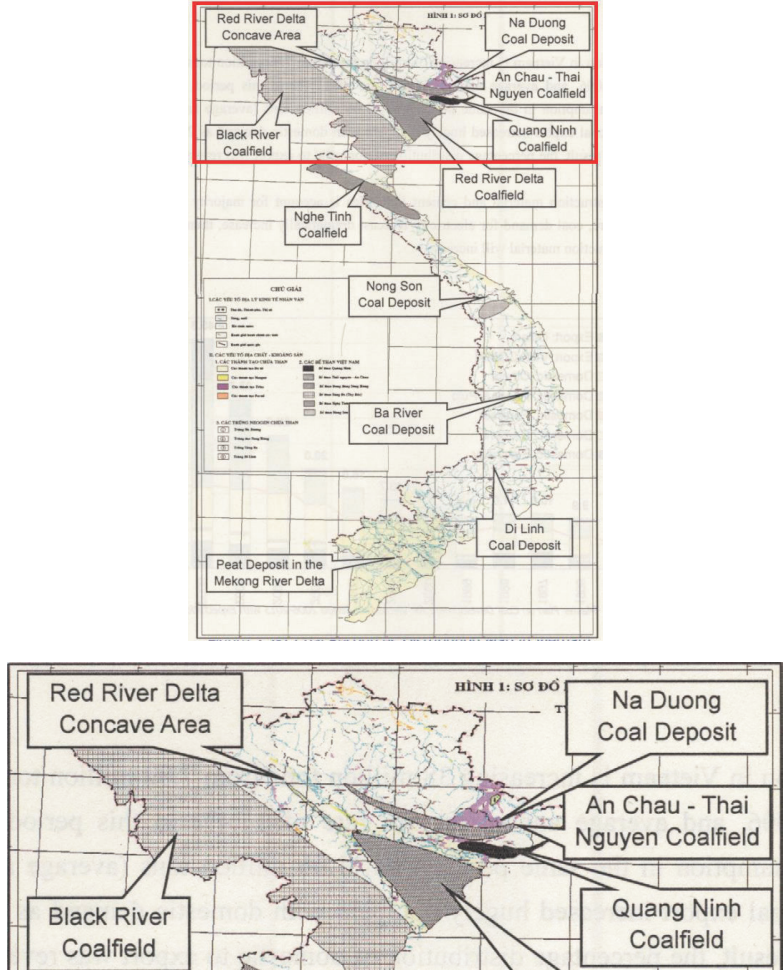

Fig.1 Major Coal Basins in Vietnam.

(Square part in the upper Fig. is expanded in lower Fig)

coal mines was in May 2004. In the case of the sub-bituminous Phan Me Coal Mine (fuel ratio: around 2.3), they might have spontaneous combustions earlier than that period; however, detailed information is not available because that coal mine belongs to Thai Nguyen Steel Company which does not belong to VINACOMIN and did not have statistical data of spontaneous combustion.

One of the interesting features of those spontaneous combustions is "short term outbreak" less than several weeks from the start of exposure of coal seam or goaf into the 
Table 1 History of spontaneous combustions in Vietnamese anthracite coal mines.

\begin{tabular}{|c|c|c|c|}
\hline Coal Mine & Coal Seam & Date of outbreak & Remarks \\
\hline \multirow{5}{*}{ Hong Thai* } & \multirow{4}{*}{ No. 24} & $(1)^{*}$ May 24,2004 & Fire started in the coal wall of starting part of the long wall coal face. \\
\hline & & $(2)^{*}$ May 16,2005 & \multirow{2}{*}{ Fire started after two months sice the goaf exposed to air leakage from the gate road. } \\
\hline & & (3)* June 4, 2005 & \\
\hline & & (4)* May, 2009 & Fire started after two months since the long wall with hydraulic frame started. \\
\hline & No. 12 & (5) September 3, 2013 & Fire started after one month since a rock entry penetrated Coal Seam No. 12 in Trang Khe Area. \\
\hline \multirow{4}{*}{ No. 91 Enterprise } & \multirow{3}{*}{ No. 5} & (1) Jan, 2007 & \multirow{3}{*}{ Fire started in the goaf of Coal Seam No. 5 into which ventilation air might leaked in. } \\
\hline & & (2) August, 2007 & \\
\hline & & (3) May, 2008 & \\
\hline & No. 4 & (4) June 2012 & Fire started after two weeks since a rock entry penetrated Coal Seam No. 4. \\
\hline \multirow{3}{*}{ Khanh Hoa** } & \multirow{3}{*}{ No. 16} & (1) May 4, 2011 & \multirow{3}{*}{$\begin{array}{l}\text { Fire started within one month of coal exposed to the air at caving place along a gallery in same } \\
\text { Coal Seam No. } 6 .\end{array}$} \\
\hline & & (2) May 29, 2011 & \\
\hline & & (3) March 2012 & \\
\hline
\end{tabular}

* (1), (2), (3) and (4) correspond to No. 1, No. 2, No.3 and No.4 in Figure 4 respectively.

** All the galleries are excavated inside the coal seam including permanent galleries.

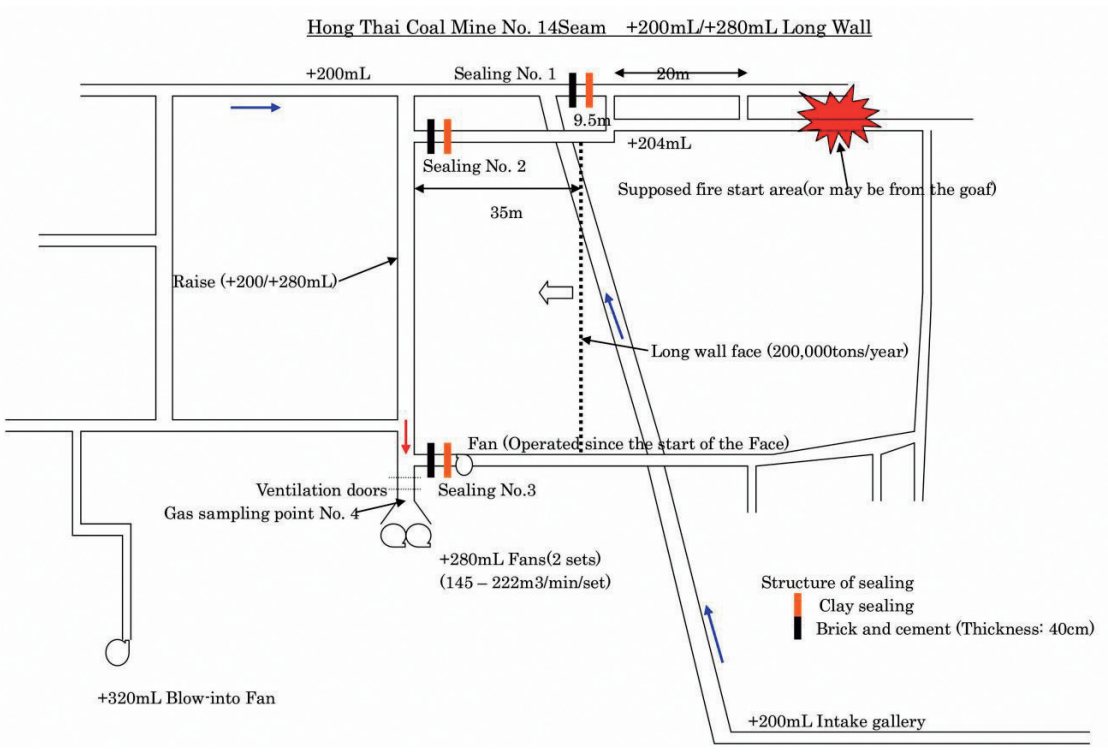

Fig.2 Schematic view of sealing walls of the mining panel of Hong Thai Coal Mine.

ventilation system. ${ }^{3)}$ An earliest case of outbreak of spontaneous combustion was around two weeks after a rock entry penetrated a coal seam as shown in the case of No. 91 Enterprise Coal Mine (see Table 1).

As a countermeasure for suppressing such spontaneous combustions, the authors suggested the relevant coal mines to install sealing walls at all the intake and exhaust galleries so as to cut air supply into the area of spontaneous combustion. An example layout of a mining panel of Hong Thai Coal Mine which started spontaneous combustion in May 2004 is shown in Fig. 2 and the picture of sealing No. 1 is shown in Fig. 3. And, we had monitored the situations of inside the sealing walls by analyzing gas, measuring differential air pressure between both side the sealing as well as monitoring air leakage through the sealing wall by smoke tubes as shown in Fig. 3. Four locations of spontaneous combustion in Coal Seam No. 24 of Hong Thai Coal Mine are shown in Fig. 4. As shown in Table 1, this Coal Seam No. 24 had three times spontaneous combustion in one year from May 2004 to June 2005 and another one in 2009 , namely from those facts, this coal seam has very higher

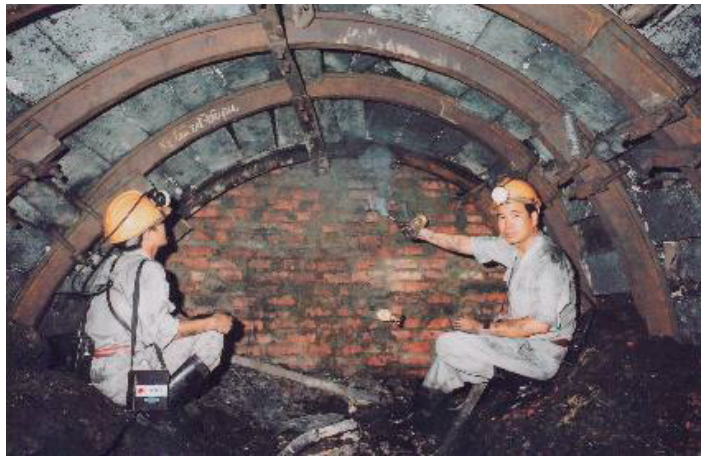

Fig.3 Sealing wall No.1 in the mining panel shown in Fig. 2.

susceptibility to spontaneous combustion.

In cases of coal spontaneous combustions at Hong Thai, Trang Khe and Khanh Hoa coal mines shown in Table 1, gas samples were taken from inside the sealing walls by using a vacuum pump and analyzed by gas chromatographs. The gas chromatograph with two detectors of FID (flame ion detector) and TCD (thermal conductivity detector) ware used, which 


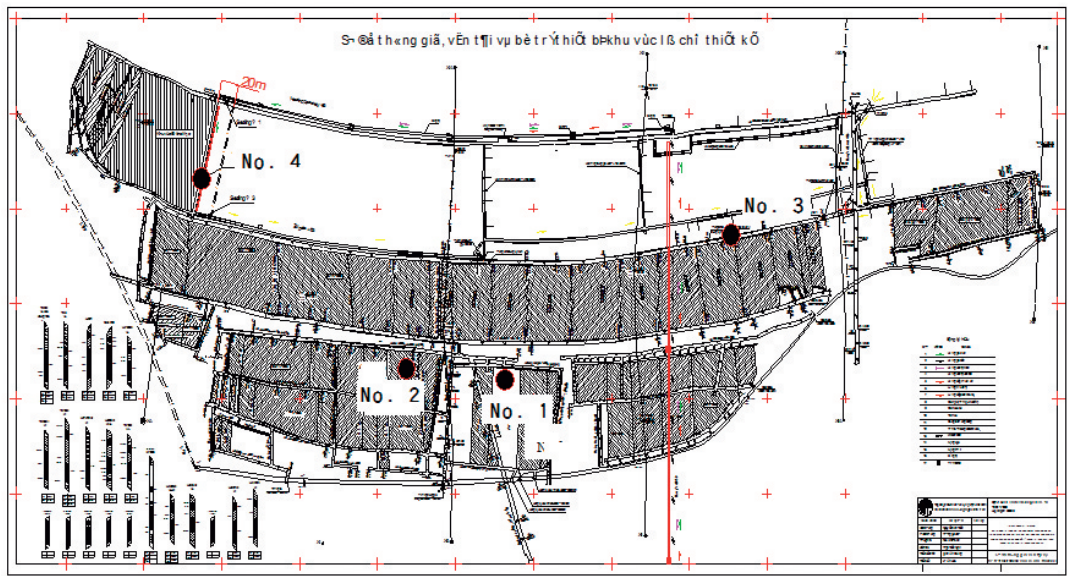

Fig.4 Locations of four spontaneous combustions in Coal Seam 24 of Hong Thai Coal Mine.

Table 2 Gas analysis results of inside the sealing No. 3 of Hong Thai Coal Mine.

\begin{tabular}{c|c|c|c|c|c}
\hline \multirow{2}{*}{$\begin{array}{c}\text { Date } \\
\text { 2004) }\end{array}$} & \multicolumn{5}{|c}{ Gas concentration (\%) } \\
\cline { 2 - 6 } & $\mathrm{O}_{2}$ & $\mathrm{CH}_{4}$ & $\mathrm{CO}_{2}$ & $\mathrm{CO}$ & $\mathrm{H}_{2}$ \\
\hline 1-Jun & 6.00 & 0.40 & 9.89 & 1.09 & 2.40 \\
\hline 2-Jun & 7.70 & 0.33 & 9.82 & 0.61 & 1.58 \\
\hline 3-Jun & 11.29 & 0.52 & 6.03 & 0.61 & 1.06 \\
\hline 4-Jun & 5.01 & 0.35 & 12.47 & 0.44 & 0.31 \\
\hline 5-Jun & 18.08 & 0.10 & 0.85 & 0.11 & 0.09 \\
\hline 6-Jun & 15.02 & 0.12 & NA & 0.11 & 0.08 \\
\hline
\end{tabular}

can detects $\mathrm{H}_{2}, \mathrm{O}_{2}, \mathrm{~N}_{2}, \mathrm{CO}, \mathrm{CO}_{2}$ and hydrocarbon gasses $\left(\mathrm{C}_{1}\right.$ $\mathrm{C}_{4}$ ) at concentration level of ppm or higher. Beside the gasses of $\mathrm{CH}_{4}, \mathrm{CO}, \mathrm{CO}_{2}$ and $\mathrm{H}_{2}$, no any other hydrocarbon gas was detected in those anthracite coal mines in Vietnam in contrast with spontaneous combustion of bituminous coal mines in other countries. ${ }^{4)}$ Some extraction of gas analysis results of the cases in Coal Sean No. 24 of Hong Thai Coal Mine in May 2004 and Coal Seam No.12 in Trang Khe Area of Hong Thai Coal Mine in September 2013 are shown in the Table 2, and Table 3 respectively. As shown in Table 1, these two spontaneous combustions occurred in different coal seams of No. 24 and No. 12 respectively.

In the case of Hong Thai Coal Mine in May 2004, the combustion area was isolated from roadway ventilation system by installing three sealing walls of No. 1, No. 2 and No. 3 of which No. 1 and No. 2 were installed in the intake galleries and No. 3 was installed in the exhaust gallery as shown in Fig. 2. From Table 2, the facts that deserve our curious attention was detection of higher concentration $\mathrm{H}_{2}$ and $\mathrm{CO}$ gasses as well as no any detection of hydrocarbon gasses except for lower level $\mathrm{CH}_{4}$ gas.

In case of Coal Seam No. 12 in Trang Khe Area of Hong Thai Coal Mine in September 2013, the fire had started at a place where a coal seam was penetrated by a rock entry heading so that only one sealing wall was enough to suppress the spontaneous combustion. Same as Table 2, higher $\mathrm{H}_{2}$ and $\mathrm{CO}$ gas concentrations were observed and no any hydrocarbon gas except for lower level $\mathrm{CH}_{4}$ gas was observed through all the analyses.

Proximate analysis and elementary analysis results of the coal samples from the coal seams which had spontaneous
Table 3 Gas analysis results of inside the sealing of Trang Khe Area of Hong Thai Coal Mine.

\begin{tabular}{c|c|c|c|c|c|c}
\hline \multirow{2}{*}{$\begin{array}{c}\text { Date } \\
(2013)\end{array}$} & \multicolumn{6}{|c}{ Gas concentration (\%) } \\
\cline { 2 - 7 } & $\mathrm{O}_{2}$ & $\mathrm{~N}_{2}$ & $\mathrm{CH}_{4}$ & $\mathrm{CO}_{2}$ & $\mathrm{CO}$ & $\mathrm{H}_{2}$ \\
\hline 4-Sept & 15.88 & 78.34 & 0.20 & 1.72 & 0.02 & 0.14 \\
\hline 5-Sept & 9.85 & 84.51 & 0.06 & 2.82 & 0.30 & 0.20 \\
\hline 6-Sept & 9.63 & 85.55 & 0.04 & 2.33 & 0.19 & 0.10 \\
\hline 7-Sept & 9.36 & 85.80 & 0.02 & 1.66 & 0.15 & 0.07 \\
\hline
\end{tabular}

combustion are shown in Table 4 and Table 5. Anthracite coals have lesser content of volatile matter less than $10 \%$, even at highest case the value is $9.4 \%$ of Khanh Hoa coal and high contents of fixed carbon more than $70 \%$ except for Hong Thai Coal Seam No. 12 which has higher ash content nearly $40 \%$. Besides that, the methane gas content of those coal seams show less than $1 \mathrm{~m}^{3} /$ ton by dry ash basis even through in-situ methane gas content measurements ${ }^{5)}$.

From proximate analysis results shown in Table 4, all coal samples can be defined as anthracite because of their bigger fuel ratios, but depend on the criteria of classification, coal sample from Khanh Hoa Coal Mine might be regarded as "semianthracite".6)

The evident of the gas analysis results clearly show that anthracite coal does not generate hydrocarbon gasses during the oxidation process. The reason might be able to deduce from the facts much less methane gas content as well as much less volatile matter in anthracite coal. In addition, anthracite contains much less hydrocarbon molecule or hydrogen element in itself comparing with bituminous as shown in Table 5 of elementary analysis. For example, in case of sub-bituminous coal of Vietnam contain $5.5 \%$ of Hydrogen as shown in Table $6 .{ }^{7)}$ From these facts, hydrocarbon gasses might hardly appear even oxidation heating process such as spontaneous combustion at mining site.

The results in Table 5 show lower hydrogen content in those anthracite coal samples. It might be difficult to explain that the source of hydrogen in Table 2 and Table 3 has come from coal itself. Then another source of $\mathrm{H}_{2}$ might be the "water gas-reaction" at the fire area with high temperature. Those might be the reactions (7) or (8) as shown in the provable many reactions in which carbon $(\mathrm{C})$, water $\left(\mathrm{H}_{2} \mathrm{O}\right)$, and other relevant 
Table 4 Proximate analysis of coal from underground coal mine in Vietnam.

\begin{tabular}{c|c|c|c|c|c|c}
\hline Coal Mine & Seam No. & $\begin{array}{c}\text { Moisture } \\
(\%)\end{array}$ & $\begin{array}{c}\text { Ash } \\
(\%)\end{array}$ & $\begin{array}{c}\text { Volatile Matter } \\
(\%)\end{array}$ & $\begin{array}{c}\text { Fixed Carbon } \\
(\%)\end{array}$ & Fuel Ratio \\
\hline \multirow{2}{*}{ Hong Thai } & 12 & 0.73 & 39.03 & 4.07 & 56.17 & 13.8 \\
\cline { 2 - 7 } & 18 & 0.56 & 14.72 & 3.29 & 81.43 & 24.8 \\
\hline \multirow{2}{*}{ No. 91 Ent. } & 5 & 3.14 & 23.20 & 6.78 & 66.88 & 9.9 \\
\cline { 2 - 7 } & 4 & 1.32 & 9.12 & 2.47 & 87.09 & 35.3 \\
\hline Khanh Hoa & 16 & 0.85 & 16.44 & 9.40 & 73.31 & 7.8 \\
\hline
\end{tabular}

Table 5 Elementary analysis of coal from underground coal mine in Vietnam.

\begin{tabular}{|c|c|c|c|c|c|c|c|c|}
\hline Coal Mine & Seam No. & $\begin{array}{l}\text { Total Sulfur } \\
(\%)\end{array}$ & $\begin{array}{c}\text { Carbon } \\
(\%)\end{array}$ & $\begin{array}{c}\text { Hydrogen } \\
(\%)\end{array}$ & $\begin{array}{c}\text { Nitrogen } \\
(\%)\end{array}$ & $\begin{array}{c}\text { Oxygen } \\
(\%)\end{array}$ & $\begin{array}{l}\text { Ash } \\
(\%)\end{array}$ & $\begin{array}{c}\text { Sulfur in Ash } \\
(\%)\end{array}$ \\
\hline \multirow{2}{*}{ Hong Thai } & 12 & 2.12 & 55.31 & 1.73 & 0.69 & 0.42 & 39.32 & 2.14 \\
\hline & 18 & 1.54 & 79.49 & 2.27 & 0.78 & 0.67 & 14.80 & 1.55 \\
\hline \multirow{2}{*}{ No. 91 Ent. } & 5 & 3.49 & 66.48 & 0.42 & 0.47 & 3.01 & 23.20 & 3.28 \\
\hline & 4 & 2.35 & 85.19 & 1.28 & 0.69 & 0.22 & 9.24 & 2.38 \\
\hline Khanh Hoa & 16 & 1.89 & 75.73 & 2.92 & 2.42 & 1.10 & 16.58 & 1.91 \\
\hline
\end{tabular}

gasses are involved:

(1) Methane gas generation:

Heat decomposition:

$\mathrm{Coal} \rightarrow \mathrm{CH}_{4}+\mathrm{C}$ (char) (exothermic)

Reaction with hydrogen:

$$
\begin{aligned}
& \mathrm{C}+2 \mathrm{H}_{2} \rightarrow \mathrm{CH}_{4}+17.9 \mathrm{kcal} / \mathrm{mol} \quad \cdots \cdots \cdots \\
& \mathrm{CO}+3 \mathrm{H}_{2} \rightarrow \mathrm{CH}_{4}+\mathrm{H}_{2} \mathrm{O}+49.3 \mathrm{kcal} / \mathrm{mol}
\end{aligned}
$$

\section{(2) $\mathrm{CO}$ gas generation}

\section{Reaction with Oxygen:}

$$
\begin{aligned}
& \mathrm{C}+\mathrm{O}_{2} \rightarrow \mathrm{CO}_{2}+97.0 \mathrm{kcal} / \mathrm{mol} \\
& 2 \mathrm{C}+\mathrm{O}_{2} \rightarrow 2 \mathrm{CO}+29.4 \mathrm{kcal} / \mathrm{mol}
\end{aligned}
$$

Reactions with Carbon Dioxide:

$$
\mathrm{C}+\mathrm{CO}_{2} \rightarrow 2 \mathrm{CO}+38.2 \mathrm{kcal} / \mathrm{mol}
$$

(3) Hydrogen gas generation:

$$
\begin{aligned}
& \mathrm{C}+\mathrm{H}_{2} \mathrm{O} \rightarrow \mathrm{CO}+\mathrm{H}_{2}-31.4 \mathrm{kcal} / \mathrm{mol} \\
& \mathrm{C}+2 \mathrm{H}_{2} \mathrm{O} \rightarrow \mathrm{CO}_{2}+2 \mathrm{H}_{2}-18.2 \mathrm{kcal} / \mathrm{mol} \quad \cdots \cdots \\
& \mathrm{CO}+\mathrm{H}_{2} \mathrm{O} \rightarrow \mathrm{CO}_{2}+\mathrm{H}_{2}+10.0 \mathrm{kcal} / \mathrm{mol}
\end{aligned}
$$

Some of those reactions may only be able to occur at the higher temperature around several hundred degrees $\left({ }^{\circ} \mathrm{C}\right)$ or so. When we implemented full scale big underground fire experiments under the condition of "fuel rich", we observed much of $\mathrm{H}_{2}$ gas in the burned gas of the fire up to $5 \%$ depend on the fire condition. From those experiences, the concentration of $\mathrm{H}_{2}$ gas might be a good indicator of the combustion temperature. $^{8)}$

\section{Gasses generated from coal heating test}

For further discussion on the results shown by Table 2 through Table 5 as well as on above discussions, coal sample heating experiments had been carried out by using a devise shown in Fig. 5. In those experiments, coal sample of around $100 \mathrm{~g}$ with particle size of less than $500 \mu \mathrm{m}$ is sealed into a cylindrical steel made container, which has two holes at both side ends for introducing a constant flow of oxygen or air. This container was located at the center of an electric furnace which has temperature control program with a constant
Table 6 Elementary analysis of sub-bituminous coal of Vietnam ${ }^{7)}$.

\begin{tabular}{c|c|c|c}
\hline Carbon & Hydrogen & Oxygen & Nitrogen \\
\hline $72.3 \%$ & $5.5 \%$ & $21.9 \%$ & $0.3 \%$ \\
\hline
\end{tabular}

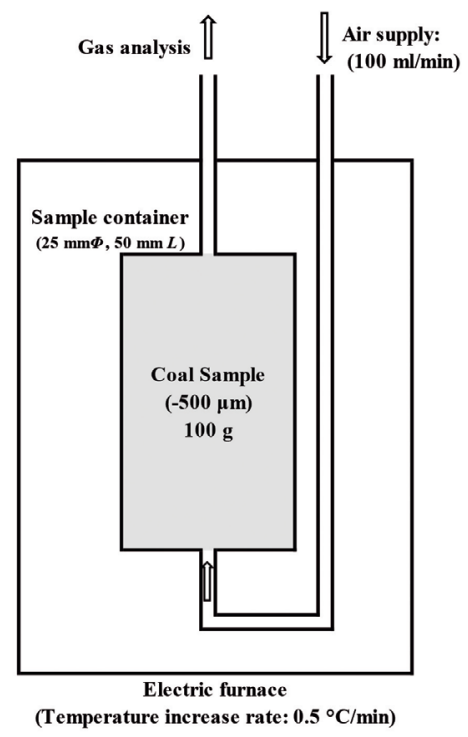

Fig.5 Schematic diagram of experimental setup for analyzing gasses from heated coal.

temperature increase rate at $0.5{ }^{\circ} \mathrm{C} / \mathrm{min}$ and a constant air supply system with a flow rate at $100 \mathrm{ml} / \mathrm{min}$ and generated gasses were analyzed by gas chromatograph. During this process, supplied air was saturated by water vapor by introducing the air through water trough by bubbling. This equipment has two temperature measuring systems; namely, one is used for controlling the temperature of the heating furnace which decides the temperature increase rate and the other one is used for measurement of the coal sample temperature during heating test. In those experiments, three anthracite coal samples from Hong Thai Coal Mine (Coal Seam No. 24), Khanh Hoa 


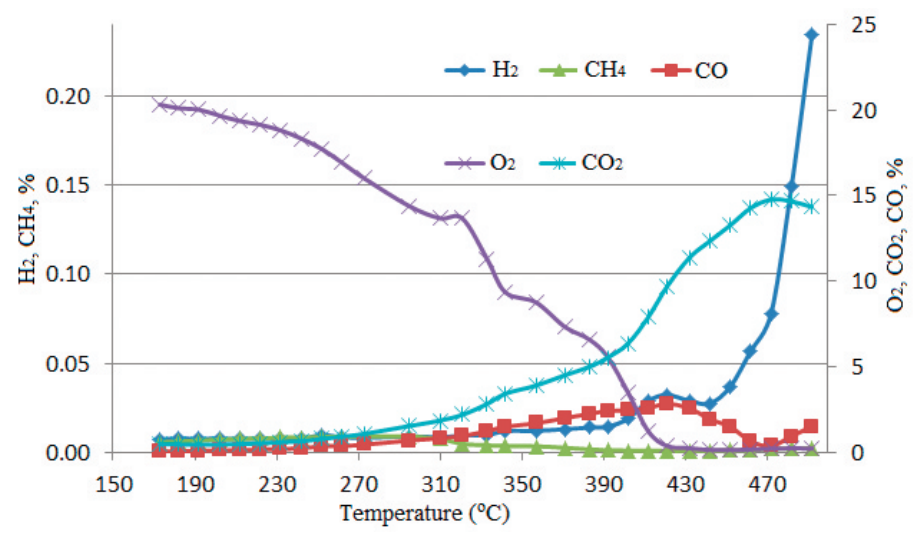

Fig.6 Gas generation from anthracite coal during heating process with air supply - Coal seam No. 4 of No. 91 Enterprise Coal Mine.

Table 7 Gas generation from anthracite coal during heating process with air supply.

\begin{tabular}{c|c|c|c|c|c|c}
\hline Coal Mine (Seam No.) & $\begin{array}{c}\text { Temperature } \\
\left({ }^{\circ} \mathrm{C}\right)\end{array}$ & $\begin{array}{c}\mathrm{O}_{2} \\
(\%)\end{array}$ & $\begin{array}{c}\mathrm{CO}_{2} \\
(\%)\end{array}$ & $\begin{array}{c}\mathrm{CO} \\
(\%)\end{array}$ & $\begin{array}{c}\mathrm{CH}_{4} \\
(\%)\end{array}$ & $\begin{array}{c}\mathrm{H}_{2} \\
(\%)\end{array}$ \\
\hline \multirow{3}{*}{$\begin{array}{c}\text { Hong Thai } \\
\text { (Seam No. 24) }\end{array}$} & $270{ }^{\circ} \mathrm{C}$ & 3.85 & 3.47 & 1.46 & 0.002 & 0.019 \\
\cline { 2 - 7 } & $283{ }^{\circ} \mathrm{C}$ & 1.16 & 9.40 & 1.79 & 0.003 & 0.033 \\
\cline { 2 - 7 } & $295{ }^{\circ} \mathrm{C}$ & 0.30 & 7.70 & 2.07 & 0.002 & 0.029 \\
\hline \multirow{2}{*}{$\begin{array}{c}\text { No. 91 Enterprise } \\
\text { (Seam №. 5) }\end{array}$} & $240{ }^{\circ} \mathrm{C}$ & 12.92 & 1.79 & 0.43 & 0.005 & 0.039 \\
\cline { 2 - 7 } & $270{ }^{\circ} \mathrm{C}$ & 4.72 & 4.34 & 0.91 & 0.007 & 0.077 \\
\hline \multirow{2}{*}{$\begin{array}{c}\text { Khanh Hoa } \\
\text { (Seam №. 16) }\end{array}$} & $306{ }^{\circ} \mathrm{C}$ & 0.00 & 9.28 & 1.22 & 0.005 & 0.089 \\
\cline { 2 - 7 } & $240{ }^{\circ} \mathrm{C}$ & 8.11 & 2.62 & 0.98 & 0.002 & 0.028 \\
\cline { 2 - 7 } & $302{ }^{\circ} \mathrm{C}$ & 0.00 & 9.53 & 2.80 & 0.003 & 0.025 \\
\hline
\end{tabular}

Table 8 Gas generation from Phan Me sub-bituminous coal during heating process with air supply.

\begin{tabular}{c|c|c|c|c|c|c|cc}
\hline $\begin{array}{c}\text { Temperature } \\
\left({ }^{\circ} \mathrm{C}\right)\end{array}$ & $\begin{array}{c}\mathrm{O}_{2} \\
(\%)\end{array}$ & $\begin{array}{c}\mathrm{CO}_{2} \\
(\%)\end{array}$ & $\begin{array}{c}\mathrm{CO} \\
(\%)\end{array}$ & $\begin{array}{c}\mathrm{CH}_{4} \\
(\%)\end{array}$ & $\begin{array}{c}\mathrm{C}_{2} \mathrm{H}_{6} \\
(\%)\end{array}$ & $\begin{array}{c}\mathrm{C}_{2} \mathrm{H}_{4} \\
(\%)\end{array}$ & $\begin{array}{c}\mathrm{H}_{2} \\
(\%)\end{array}$ \\
\hline 182 & 15.94 & 0.62 & 0.20 & 0.038 & 0.002 & 0.0004 & 0.015 \\
\hline 230 & 0.18 & 3.47 & 1.56 & 0.088 & 0.017 & 0.013 & 0.043 \\
\hline 282 & 0.33 & 7.27 & 2.72 & 0.058 & 0.007 & 0.010 & 0.023 \\
\hline
\end{tabular}

Coal Mine and No. 91 Enterprise Coal Mine, and one subbituminous from Phan Me Coal Mine were used. Experimental results of anthracite are shown in Fig. 6 and Table 7 and experimental results of sub-bituminous are shown in Table 8. (Because the apparatus shown in Fig. 5 was handmade, gas sampling was conducted manually and analyzed by a micro-gaschromatograph so that the temperature shown in Table 7 and Table 8 are not same values due to sampling and analysis time.)

In case of anthracite coal samples from Coal Seam No. 4 of No. 91 Enterprise Coal Mine as shown in Fig. 6, $\mathrm{O}_{2}$ gas starts to decrease gradually from nearly $200{ }^{\circ} \mathrm{C}$, and $\mathrm{CO}_{2}, \mathrm{CO}$ and $\mathrm{H}_{2}$ start to increase from around $250{ }^{\circ} \mathrm{C}$ and on the other hand, $\mathrm{CH}_{4}$ generates from much lower temperature at an almost constant concentration and in addition no any hydrocarbon gas comes out through all the temperature range. This tendencies are same even in case of other anthracite coal samples from other three coal mines as shown in Table 6 . In these tests, $\mathrm{H}_{2}$ gas starts to appear from around $200{ }^{\circ} \mathrm{C}$ or $250{ }^{\circ} \mathrm{C}$ and no any higher grade hydrocarbon gasses $\left(\mathrm{C}_{2}\right.$ or higher) was observed throughout the experiments. From those facts, it might be possible to deduce that $\mathrm{CH}_{4}$ gas might come appear from desorption due to increase of the temperature of coal itself and on the other hand ${ }^{9)}$, other gasses such as $\mathrm{CO}_{2}, \mathrm{CO}$ and $\mathrm{H}_{2}$ might come appear by some chemical reaction during heating process.

As shown in the temperature range greater than $450{ }^{\circ} \mathrm{C}$ of Fig. $6, \mathrm{H}_{2}$ gas increases quite rapidly along with increase of the temperature of coal sample and $\mathrm{CO}$ gas decreases in contrast to the increase of $\mathrm{H}_{2}$ gas at temperature range from $430{ }^{\circ} \mathrm{C}$ to $470{ }^{\circ} \mathrm{C} . \mathrm{CO}_{2}$ gas also shows a tendency of coming the ceiling at same temperature range and in addition, $\mathrm{O}_{2}$ gas becomes almost "zero" after $400{ }^{\circ} \mathrm{C}$. From these data, the environment inside the coal sample container become "reduction atmosphere" dominated together with slight oxidation so that some reactions such as reactions (7), (8) or (9) might be easy to occur.

Even in other experiments of anthracite as shown in Table 6 , it may be possible to understand that no any hydrocarbon gas except for $\mathrm{CH}_{4}$ gas comes out and $\mathrm{H}_{2}$ gas appears during heating process. Although it is not clear that how much extent of site conditions of spontaneous combustion are represented in the series of coal sample heat tests by using the set-up shown in 


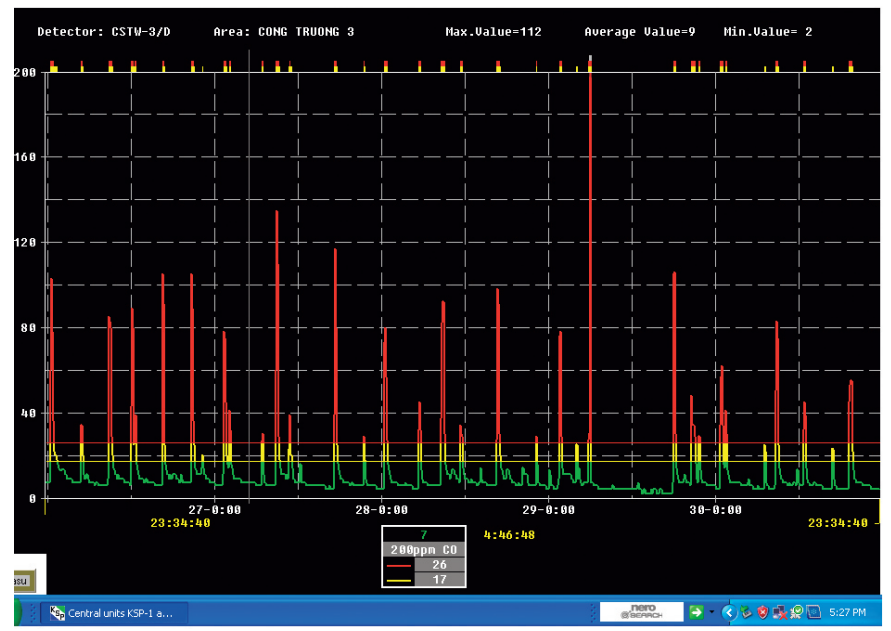

Fig.7 CO gas concentration change due to blasting at coal seam No. 4 of No. 91 Enterprise Coal Mine (From display of central monitoring system).

Fig. 5, it might be able to deduce qualitatively that the analyzed results of site sampled gasses has some similar characteristics with gasses generated from artificial heating tests of coal samples with some air flow.

Apart from these tests of anthracite, an example result of artificial heating test of sub-bituminous from Phan Me Coal Mine is shown in Table 8. In this test, some discriminative points were observed such as: (1) hydrocarbons of $\mathrm{C}_{2} \mathrm{H}_{4}$ and $\mathrm{C}_{2} \mathrm{H}_{6}$ with concentrations around hundreds ppm were found together with $\mathrm{CH}_{4}$ from lower temperature around $200{ }^{\circ} \mathrm{C}$ or less, (2) rapid oxidation processes might occur from much less temperature than the case of anthracite from around $190{ }^{\circ} \mathrm{C}$ and then $\mathrm{O}_{2}$ gas becomes almost zero at around $230{ }^{\circ} \mathrm{C}$ which is $200{ }^{\circ} \mathrm{C}$ lower than the case of anthracite and (3) even after the atmosphere inside the coal sample holder becomes "complete reduction atmosphere" at the temperature range greater than $230{ }^{\circ} \mathrm{C}$, there is not so much change in generations of $\mathrm{H}_{2}, \mathrm{CO}, \mathrm{CO}_{2}$, $\mathrm{C}_{2} \mathrm{H}_{6}$ and $\mathrm{C}_{2} \mathrm{H}_{4}$. The other gasses of $\mathrm{CO}$ and $\mathrm{CO}_{2}$ show not so much differences from the cases of anthracite in all the tested temperature range from the cases of anthracite.

\section{Indication gasses of spontaneous combustion of anthracite}

The first gas indices for spontaneous combustion was proposed by J. I. Graham who focused mainly into $\mathrm{CO}, \mathrm{CO}_{2}$ released and $\mathrm{O}_{2}$ concentration decreased during coal oxidation process and those have been widely used worldwide under the name Graham's ratios ${ }^{10)}$. Depend on the applied method and coal rank in each country, many researches are focusing on the other hydrocarbon gasses generated during coal oxidation process $\left(\mathrm{C}_{2} \mathrm{H}_{6}, \mathrm{C}_{2} \mathrm{H}_{4}, \mathrm{C}_{2} \mathrm{H}_{2} \mathrm{C}_{3} \mathrm{H}_{8}, \mathrm{C}_{3} \mathrm{H}_{6} \text {, etc. }\right)^{11)}$. In the researches done by an Indian researcher, the mine fire gas indicators were proposed such as production of $\mathrm{CO}$, disappearance of $\mathrm{CO}$, oxygen consumption, $\mathrm{CO} / \mathrm{CO}_{2}$ ratio, Willet's ratio, $\mathrm{C} / \mathrm{H}$ ratio, $\mathrm{CO} / \mathrm{CO}_{2}$ deficiency ${ }^{12)}$. Those most of researches on gas indicators for coal spontaneous combustion rely on the generation of hydrocarbon gasses as well as carbon monoxide, carbon dioxide and oxygen deficiency at the temperature range less than $100{ }^{\circ} \mathrm{C}$. In a Japanese reference handbook on coal spontaneous combustion of bituminous coal mines, generation of many kinds of hydrocarbon gasses such as $\mathrm{C}_{2} \mathrm{H}_{6}, \mathrm{C}_{2} \mathrm{H}_{4}, \mathrm{C}_{3} \mathrm{H}_{8}, \mathrm{C}_{3} \mathrm{H}_{6}$ and $\mathrm{C}_{2} \mathrm{H}_{2}$ in addition with $\mathrm{CO}$ and $\mathrm{CO}_{2}$ are introduced ${ }^{13)}$.

From the results of site sampled gas analysis from inside the sealing of spontaneous combustion as well as from the tests of anthracite coal oxidation, it was shown that the tendency of gas generation during spontaneous combustion of anthracite coal is quite difference from other type of coal. One important feature is generation of only two gasses of $\mathrm{CO}$ and $\mathrm{H}_{2}$ during heating process both of which do not exist in the ambient ventilation air and another important point is no generation of hydrocarbon gasses except for $\mathrm{CH}_{4}$ gas which might be released into ventilation even under the mine operation ambient temperature. From such situation, it might be possible to use the relationship between $\mathrm{CO}$ and $\mathrm{O}_{2}$ generated during coal heating as one of indicator for coal heating process of anthracite coal; however, blasting are conducted quite often and some heavy diesel engine machines are used at area of nearby intake galleries so that $\mathrm{CO}$ gas might not be able to be used as an indicator gas. ${ }^{6}$ (see Fig. 7)

Hence, for detecting a spontaneous combustion of anthracite coal mines in Vietnam, $\mathrm{H}_{2}$ gas in exhaust ventilation might be only one important indicator.

\section{The site mining condition and the cause of spontaneous combustion}

Recently, spontaneous combustions have occurred at four coal mines in Vietnam. Beside the susceptibility to spontaneous combustion of anthracite itself, some site factors might promote this phenomenon.

For all those coal mines, the spontaneous combustion had started from the end of dry season (August - March) to start or period of rainy season (April - July). Among twelve (12) reported spontaneous combustions shown in Table 1, eight (8) of them have occurred in May (6 times) and June (2 times) others have occurred one time in January, March, August and September respectively.

Mining skeleton design also has important role for preventing spontaneous combustion. Most coal mine have 


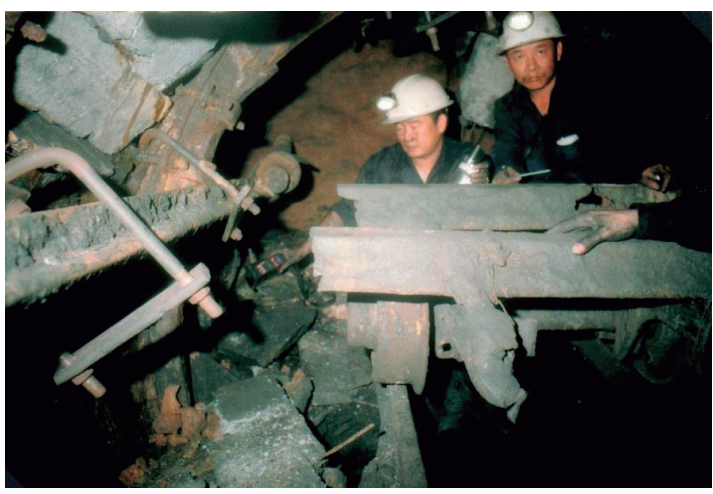

Fig.8 Narrowing of return gate roadway due to floor heave at Hong Thai Coal Mine.

poor safety coal pillars between worked out panel and newly developing panel which have to protect the return gate roadway for the next coal winning panel. By the rock pressure effect from the former coal winning panel, the return gate cross section size reduces, which results into easier introduction of the intake air into the goaf area and outbreak of spontaneous combustion. An example of a narrowed return gate road is shown in Fig. 8 in which narrowing of the gallery and floor heave can be found by the lifting up of the rail of the gallery floor up to near the ceiling of the return gate. Fig. 8 was taken at the return gate of the long wall face behind of which No. 4 spontaneous combustion had started in the goaf as shown in Fig. 2 and Table 1.

At some coal mines, even the permanent galleries are located inside the coal seam to be developed. The air can be penetrated from the gallery to coal seam through crack system around galleries as well as water penetration from surface might cause introduction of fresh air after dripping or drying the penetrated water. For example, locations of the place of spontaneous combustion from ground surface are as follows:

Hong Thai Coal Mine: $10 \mathrm{~m}-76 \mathrm{~m}$

No. 91 Enterprise Coal Mine: $31 \mathrm{~m}-54 \mathrm{~m}$

Khnah Hoa Coal Mine: 30 m - 40 m

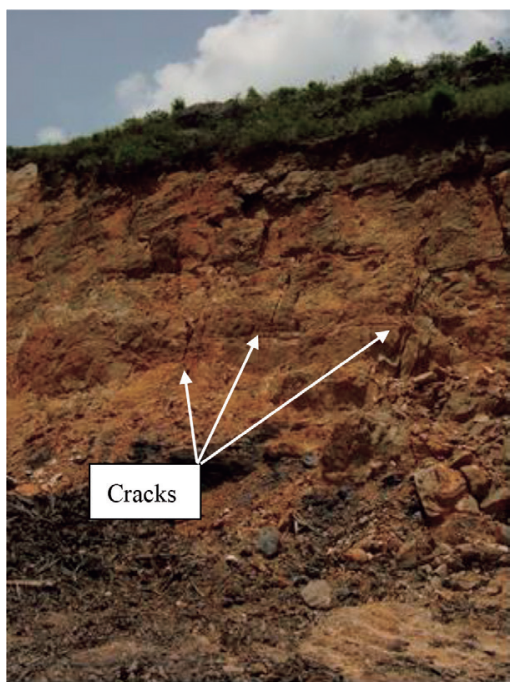

Fig.9 Surface cracks of rock seam above a spontaneous combustion of Hong Thai Coal Mine.
Namely, all the spontaneous combustions occurred at very shallow places. Ground surface conditions above spontaneous combustion area are shown in Fig. 9 and Fig. 10. From the above shown facts, systematic countermeasures have to be developed for preventing spontaneous combustion at anthracite coal mines in Vietnam.

\section{Conclusion}

In case of spontaneous combustion of anthracite, from not contained gasses in usual ambient air only $\mathrm{H}_{2}$ and $\mathrm{CO}$ were observed in the sample gas from inside the sealing in contrast with bituminous coal which generates various hydrocarbon gasses. Heating tests of several anthracite coal samples with some amount of fresh air flow supported the actual site phenomena shown above, namely, it was also shown that $\mathrm{H}_{2}$ and $\mathrm{CO}$ gasses were observed together with trace $\mathrm{CH}_{4}$ gas as well as no any hydrocarbon gas from $\mathrm{C}_{2}$ or higher grade was observed. Hence, $\mathrm{H}_{2}$ might be one of important indicator for spontaneous combustion of anthracite coal.

Besides the characters of spontaneous combustion of Vietnamese anthracite coal mines, there are many points which have to be improved from the viewpoints of prevention of spontaneous combustion. Even the feature and the susceptibility to spontaneous combustion of anthracite coal differ from other type of coal, the site conditions which result into outbreak of spontaneous combustion are not different from the others. Then the experiences in the prevention measures of spontaneous combustion of bituminous coal can also be useful for anthracite coal mine in Vietnam.

\section{References}

1) Coal Mining Research Center and MMIJ:“Coal Mine Safety Technology Handbook - No. 3: Spontaneous Combustion”, (March 1990), pp.4 - 5 (from Figure 2.1) [Japanese :「炭鉱保 安技術要覧 第 3 編 自然発火」, (財) 石炭技術研究所・資源・素材学会, 平成 2 年 3 月].

2) The Institute of Energy Economics, Japan and Tokyo Electric Power Company: "A study on National Energy Master Plan - Progress Report", 24th July 2007, p.60.

3) Coal Mining Research Center and MMIJ: "Coal Mine Safety Technology Handbook - No. 3: Spontaneous Combustion”, (March 1990), p.8 (from Table 2.3) [Japanese：「炭鉱保安技 術要覧第 3 編 自然発火」, 石炭技術研究所・資源・素材学会, 平成 2 年 3 月 $]$.

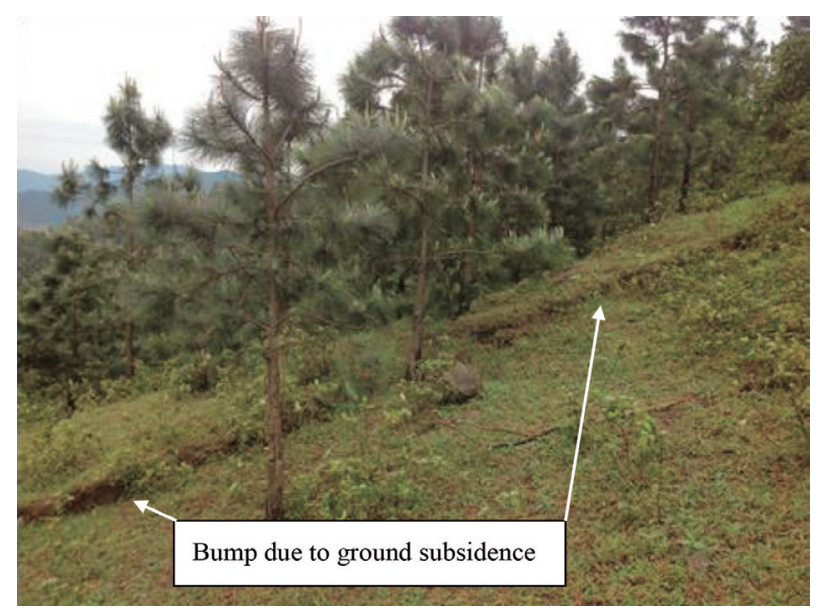

Fig.10 Ground subsidence above goaf area of No. 91 Enterprise Coal Mine. 
4) Coal Mining Research Center and MMIJ:"Coal Mine Safety Technology Handbook - No. 3 : Spontaneous Combustion”, (March 1990), p.17 (including Figure 3.1) [Japanese :「炭鉱保 安技術要覧 第 3 編 自然発火」, 石炭技術研究所・資源・素材学会, 平成 2 年 3 月 $]$

5) Ministry of Industry \& Trade of Vietnam: Annual report of coal mine classification on its gas content and gas emission., 2014-2016.

6) Campbell M. R. and White D.: 1915, Contributions to economic geology (short papers and preliminary reports), 1913, Part II, Mineral fuels (Petroleum, natural gas, coal and lignite), United States Geological Survey, Bulletin 581 (p.254)

7) JCOAL: "Outline of Coal Fields of World", March 1999, p.430 [Japanese :「世界の炭田 概要」, (財) 石炭エネルギーセンター, 平成 11 年 3 月 ].

8) Coal Mining Research Center and MMIJ:“Coal Mine Safety Technology Handbook - No. 4: Underground Open fire”, (March 1990), pp.5 - 7 [Japanese：「炭鉱保安技術要覽 第 4 編坑内火災」, (財) 石炭技術研究所・資源・素材学会, 平成 2 年 3 月 ].

9) Coal Mining Research Center and MMIJ:“Coal Mine Safety Technology Handbook - No. 3 Spontaneous Combustion”, (March 1990), p.17 (from Figure 3.1) [Japanese : 「炭鉱保安 技術要覧第 3 編自然発火」, (財) 石炭技術研究所·資源・素材学会, 平成 2 年 3 月 ]
10) S. C. Banerjee: Spontaneous Combustion of Coal and Mine Fires, (A. A. BALKEMA, Rotterdam, 1985), pp.70-74

11) Lukas Snopek, Alois Adamus 2012, A brief overview of development in the use of indicator gasses for coal spontaneous combustion and prospects for further solution, Geo Science Engineering Volume LVIII(2012) No3, pp.15-19.

12) Coal Mining Research Center and MMIJ:"Coal Mine Safety Technology Handbook - No. 3: Spontaneous Combustion”, (March 1990), pp.69-82 [Japanese :「炭鉱保安技術要覧 第 3 編 自然発火 , (財) 石炭技術研究所・資源・素材学会, 平成 2 年 3 月 ]

13) Coal Mining Research Center and MMIJ:"Coal Mine Safety Technology Handbook - No. 3 : Spontaneous Combustion”, (March 1990), pp.17 - 24(from Figure 2.1) [Japanese : 「炭鉱 保安技術要覧第 3 編 自然発火」，(財) 石炭技術研究所・資源・素材学会，平成 2 年 3 月].

\section{ベトナムの炭鉱における無煙炭の自然発火特性*}

\section{Le Trung TUYEN ${ }^{1} \quad$ Nhu Viet TUAN ${ }^{2}$ 大 賀 光 郎 $^{3}$ 井 清 武 弘 4}

無煙炭は自然発火し難いと一般的に言われてきたが，ベトナム の無煙炭炭鉱においては 2004 年以降，幾つかの炭鉱において自 然発火が多発するようになってきている。筆者等は，これら全て の自然発火事象の調査と対策に関わってきている。また，亜瀝青 炭を採掘する一炭鉱における数回の自然発火事象についても調査 を行った。本論文では無煙炭の自然発火の特性を中心に検討を行 う。この中で, 無煙炭の自然発火の指標ガスとして, 瀝青炭など に見られる炭化水素系ガスは発生せず，一酸化炭素と水素の二種 類のガスに限定されることを明らかにするとともに，自然発火防 止の観点から現場の採掘条件の問題点などについても検討寸る。
*2016年 7 月 7 日受付 2016 年 10 月 13 日受理

1. ベトナム VINACOMIN 鉱山科学技術研究所鉱山保安セ ンター 副所長

2. ベトナム VINACOMIN 鉱山科学技術研究所鉱山保安セ ンター 前所長

3. 正会員 工学博士 NPO 地下資源イノベーションネット ワーク

4. 正会員 工学博士 ベトナム鉱山科学技術研究所アドバイ ザー( 元資源環境技術総合研究所)

キーワード：自然発火，無煙炭，炭鉱，ベトナム，指標ガス 